\title{
CONTROL SYSTEM OF PUBLIC ADMINISTRATION: AZERBAIJAN EXAMPLE
}

\author{
Khatai SALMANOV
}

Azerbaijan State Academy of Administration, Baku, Azerbaijan

\author{
(C) The Author(s) 2021
}

\section{ABSTRACT}

The control system in public administration ensures the legitimate, effective and efficient functioning of management, contributes to achievement the specific goals. The main purpose of the control system used in public administration is to ensure the legitimacy of management activities, their implementation within the established norms and standards. The control process includes the establishment of norms and standards, the comparison of available results with the established standards, as a result of the comparison, the detection of deviations and illegal situations and the elimination of such cases. The subject of the research is the control system in public administration at the example of Azerbaijan. Based on the subject, the features of the state control system in the Republic of Azerbaijan and the state control mechanism were generally analyzed. In this direction, first of all, the main structural elements of the control mechanism, the stages of implementation of control, principles, methods, forms of control, the aspects of control were determined and each structural element was analyzed separately. The main purpose of the research paper is to study the role and importance of the control system in public administration and to systematize the scientific and theoretical approaches regarding this area. The importance of the research paper consists of the proposals for improving the state control mechanism. The research paper is compiled on scientifictheoretical approaches and analysis. At the end of the research paper, conclusions and recommendations were made in accordance with the research.

C2021.All rights reserved.

\section{ARTICLE HISTORY}

Received: 22/02/2021

Accepted: $10 / 06 / 2021$

Published online: 01/10/2021

\section{KEYWORDS}

Constitution, state, society, finance, public administration, Azerbaijan 


\section{Introduction}

In modern times, it is impossible to imagine public administration without a system of control. The complexity of management features and the rapid development of social, public, economic and legal relations have made it necessary to exercise control in public administration.

The system of state control has penetrated into all spheres of public administration and public life. Control in management reduces internal uncertainty, prevents chaos and irregularity, and ensures development. Through the control system, the state achieves the efficiency and effectiveness of management activities. The main purpose of the state in applying the system of control in management is not to punish, but to identify and eliminate existing deviations and to ensure the transparent and efficient activity of state authorities. The research paper examined the main forms of state control, financial control, judicial control, constitutional control, social control, public control and their features.

The research paper sought answers to the following questions; "What is the role and importance of control in public administration?", "What methods and principles are used for control?", "What are the main forms of state control?", "What are the features of the forms of state control and the stages of implementation?"

The research paper sought answers to the above-mentioned questions, analyzed the process of state control in general, and as a result of the research, the importance, role of control, and the impact on managerial performance were identified.

At the same time, the control system of public administration was analyzed in the Republic of Azerbaijan. First, the features and stages of fulfillment of the state control system in Azerbaijan were studied and the bodies exercising control were indicated. Then the state financial control in Azerbaijan, its forms (customs control, budget control, tax control, currency control, banking control), and its features were analyzed separately. A number of statistical graphs were used in the analysis of public financial control. These statistical graphs compare the results of the forms of financial control over the years. In addition, the main forms of state control in Azerbaijan, constitutional 
control, judicial control, public control, presidential control were analyzed. The formation of the state control system in Azerbaijan is connected with the name of the Great Leader Heydar Aliyev. After gaining independence, there was a lack of control and serious indiscipline in the field of public administration in the Republic of Azerbaijan. There was a crisis in the economic, social, political, legal, and other sectors. As a result of the far-sighted and efficient policy of the Great Leader Heydar Aliyev, who was in the power in such conditions, in a short period of time, indiscipline in the field of public administration was eliminated in Azerbaijan and a system of state control was formed. Today, Mr. President Ilham Aliyev successfully continues the system of state control that was established by Great Leader, Haydar Aliyev.

\section{State control system}

The term "control" comes from the French word "controle" and means to conduct inspections, to observe. Management control activities are carried out in two directions. The control measures carried out in the first direction include compliance with the legislation and compliance with the requirements of legislative acts. The control measures carried out in the second direction include measures taken to determine the current real situation, compare the results with the standards and adapt to possible changes. The control process is carried out in three successive stages. These steps are as follows (Rzayev, 2011:264);

- Defining standards.

- Comparison of the obtained results with the established standards.

- Evaluation of final results.

The first step in the control process is to set standards. Standards refer to the normative standards used in the comparison. Defined standards play an important role in evaluating results. Thus, the current state of the object of control is assessed on the basis of standards. At the same time, the following planning work is carried out in the first stage of the control process (Abbasov, 2013:205);

- Defining goals.

- Definition of strategic plans. 
- Definition of efficiency indicators.

The results obtained in the second stage of the control process are compared with the established standards. This, in the second stage, a comparison of the established standards with the actual results of the object of control is carried out and the existing deviations are identified. Comparisons determine the extent to which the set goals are achieved. In the third stage of the control process, the results are evaluated and appropriate measures are taken to eliminate shortcomings and deviations. The third stage of the control process is important in that the deviations that have taken place will not be repeated in the future. The main purpose of management control is not to punish, but to identify and eliminate existing negative situations. A number of issues and especially the human factor must be taken into account when organizing control activities. Failure to take these factors into account can adversely affect the effectiveness of the management process. The following factors should be considered to avoid the negative effects of the control system (Aliyev, 2012:303);

- The standards set during the control activities must be understood, accepted and enforceable.

- Mutual communication must be ensured during control activities.

- Control activities should not be tedious, overly strict or inappropriate.

- Entities that operate legally and comply with standards should be rewarded.

Control activities are divided into three forms according to the time of occurrence (Aliyeva, 2012:264);

- Initial

- Current

- Final

Initial control is carried out before the start of the activity process. This form of control is implemented in the form of inventory and accounting (accounting, finance and statistics). During the initial control, a plan for the organization and implementation of control activities is developed. Preliminary control plays an important role in preventing future deficiencies and negative situations. Current control is carried out during the course of the activity process. Current control plays an important role in 
detecting and eliminating existing deficiencies. Final control is carried out after the end of the activity. In some sources, the concept of final control is used in the form of subsequent control, followed by control (Rzayev, 2008:307).

During the final control, the reported results of the completed activity process are compared with the actual results. The comparison determines whether there are deviations. One of the key factors in the control process is the acquisition, analysis and use of data. The use of information is carried out in a phased, regular and sequential manner. The information obtained during the control process is used in the following sequence;

- Obtaining information,

- Processing of the obtained data,

- Data evaluation

During the control process, formal and informal information is used. Formal information means information that has an official status. Formal data play a special role in revealing existing deficiencies and deviations. Informal information is information that is not reflected in official documents. Informal information plays a special role in improving the control process and increasing its effectiveness.

In general, the information used in the control process must be accurate, unadulterated and complete. Incorrect information will negatively affect the results of control activities and reduce the effectiveness of control (Abbasov, 2013:205).

A number of researchers and scientists have studied the control system. J.Sismondi, A.Vagner, F.Yusti, O.Mirabo, M.Friedman, A.M.Tarasov, V.Q.Afanasyev, Tikhomirov, Robert M. Falmer and others. Researchers have conducted research on the formation and improvement of the control system in various areas of management. V.G.Afanasyev explained the concept of control as checking the compliance of the facility with management decisions, laws, norms and standards. According to him, control is a conscious, purposeful tool of guidance. Tikhomirov explained state control as a function of government. According to Tikhomirov, the state, through control, check and evaluates the implementation of laws, legal acts and documents. 
A.M.Tarasov defined control as a function of management According to him, control, as a function of management, combines three elements;

- Obtaining the necessary information,

- Analysis and evaluation of the obtained information,

- Identification of deviations and assessment by normative legal acts.

At the same time, A.M.Tarasov noted that the main purpose of control is not to observe, to conduct inspections, to inform the authorized bodies about the results of observations and inspections. According to him, control is carried out not only to reveal deviations, but also to improve the activity, prevent deviations and prevent their recurrence in the future. Thus, Tarasov characterized the defining, organizational and preventive features of control.

In addition, there are a number of approaches to the organization of control in modern times. Modern approaches to the organization of control in management can be classified as follows. Thus, control should be (Hajiyev, 2010:101);

- Comprehensive

- Consistent with the organizational structure

- Flexible

- Regulatory

- Impartial

Control is a set of processes that ensure the achievement of goals. The control process consists of defining standards, comparing existing results with established standards, and making adjustments as needed. The control system, which is an important element of the state regulatory mechanism, promotes the social, economic, social and legal development of the state and plays an irreplaceable role in achieving the set goals.

The control system applied in public administration serves the following purposes;

- Ensuring the activities of state bodies within the framework of lawful and established standards, 
- Detection and elimination of negative situations in the activities of state bodies,

- To achieve the set goals in full and on time,

- Ensuring efficient and purposeful use of resources,

- Ensuring transparency of accounting operations and reports;

Forms of the state control system are based on a number of principles. These principles play an important role in ensuring transparency in the control process. The control system in public administration is implemented on the basis of the following principles (Rzayev, 2008:310);

- The principle of independence

- The principle of the rule of law

- The principle of objectivity

- The principle of transparency

- The principle of efficiency

According to the principle of independence, which is the main principle of the state control system, control bodies must carry out control activities freely and without any dependence. At the same time, cases that undermine the independence of control activities must be prevented. The principle of the rule of law. According to this principle, the requirements of the legislation must be strictly observed and those who commit illegal acts must be brought to justice. Forms of state control must be implemented democratically. The principle of objectivity. The control process must be carried out correctly and fairly. Misleading information and other inaccuracies should not be allowed during control activities. The principle of transparency. According to this principle, the public should be informed about the results of control activities carried out in government agencies, except for confidential information. The principle of transparency plays an important role in studying the real situation of government agencies. The principle of efficiency. According to this principle, resources must be used efficiently, losses must be prevented and maximum results must be achieved with a minimum use of resources. One of the most important conditions is the effectiveness of the control system in public administration. An effective control system ensures 
complete excellence and efficiency in management (Hajiyev 2011:28). An effective control system in public administration has the following features (Gandilov, 2010:320);

- Purposeful

- Effective

- Timeliness

- Flexible

- Simple

- Economical

The main purpose of the control system applied in public administration is to ensure the lawful and efficient operation of management, to control the implementation of the management process in accordance with established norms and standards, to ensure the rule of law. State control is necessary in terms of maintaining stability, increasing the efficiency of governance, ensuring the rule of law, and protecting the rights and freedoms of individuals. The following main forms of the state control system are available (Mahmudov, 2012:343);

- Financial control

- Judicial control

- Constitutional control

- Social control

- Public control

- Other forms of state control

\subsection{State Financial Control}

Public financial control covers such processes as the establishment of financial funds, the distribution of financial resources and control over their proper use in order to ensure the economic development of the state. Financial control, which occupies an important place in the system of state control, has the following objectives (Bagirov and Hasanli, 2011:384); 
- To ensure economic and financial stability,

- To ensure the implementation of financial policy,

- To ensure the efficient distribution and use of financial resources,

- To achieve full and timely fulfillment of financial obligations,

- To ensure nursing compliance with the Constitution and financial legislation.

The process of financial control includes all operations related to the use of funds. Public financial control has a number of responsibilities to achieve the set goals. These responsibilities are necessary conditions for strengthening the rule of law, efficient use of funds and financial discipline in financial activities. The tasks of state financial control are as follows (Hajiyev and Shahrza, 2012:346);

- Control over the formation of financial budgets

- Control over the correct and efficient use of financial resources

- Control over observance of the Constitution and financial legislation

- Control over the accuracy of financial statements

- Control over abuse of financial activities.

In modern world practice, the basic principles of the organization of financial control have been identified. These principles ensure transparency in public financial control. The main principles of public financial control can be classified as follows (Muslimov and Kazimov, 2011:312);

- The principle of independence. Supervisors carrying public financial control out must operate completely independently and have no dependencies.

- According to the principle of independence, which is the main principle of public financial control, cases that undermine the independence of control activities must be prevented.

- The principle of transparency. The public should be regularly informed about the results of financial control. At the same time, the results of financial control should be published in the media. 
- The principle of the rule of law. Public financial control must be carried out on the basis of relevant financial legislation and constitutional principles. Illegal and other cases arising during financial control must be resolved within the relevant legislation.

- The principle of objectivity. Factors that negatively affect the control activity should be avoided and the objectivity of the control process should be ensured. The information obtained during the control activity must be impartial, reasonable and relevant.

- The principle of responsibility. Authorized representatives exercising state financial control must be responsible in the performance of their duties. During financial control, two parties have responsibilities: Liability of the subject of control and responsibility of the object of control.

1. Liability of the subject of control means the responsibilities of the authorized representatives exercising control in the performance of their duties.

2. Liability of the object of control means the responsibility of the object of control for illegalities and other negative circumstances revealed during the control activity.

The principle of Systemness. Measures taken during financial control should be implemented in an orderly and systematic manner. At the same time, financial control must be carried out continuously and regularly. The principles of organization of public financial control are interrelated. Violation of the requirements of these principles will have a negative impact on the overall financial control system.

Depending on the area of financial control, it is divided into the following types;

- Budgetary control

- Tax control

- Customs control

- Insurance control

- Currency control

- Banking control 
Budgetary control consists of a set of control measures carried out to check the distribution and use of budgetary funds, justification of budget revenues and expenditures, timely and complete implementation of budget processes. Tax control consists of a set of control measures that ensure the timely and complete payment of taxes, prevention of tax evasion, correct calculation of taxes and compliance with tax legislation in general. Customs control consists of a set of control measures carried out to ensure compliance with relevant customs legislation, financial acts, and international customs agreements. Insurance control is a set of processes such as analysis of the performance of insurance authorities, fulfillment of insurance obligations, achievement of set goals and verification of lawful activity of insurance subjects. Currency control is a set of control measures performed in order to regulate the national currency market by appropriate legal methods. Banking control is a set of control measures carried out to inspect the activities of commercial banks and credit organizations.

Financial control plays an important role in ensuring the socio-economic development of the state and the management of the financial system. In modern times, the formation of transparent financial control has a special place in the economic policy of the world (Khankishiyev, 2012:41).

\subsection{State Judicial Control}

One of the main forms of state control in modern times is judicial control. The formation of state judicial control is one of the main conditions of the rule of law. State judicial control means control over the lawful activity of executive and legislative state bodies by judicial bodies. In the scientific literature, judicial control is considered to be the most effective means of ensuring the legal functioning of state bodies. State judicial control has the following features (Huseynov, 2017:136);

1. State judicial control is carried out by independent, free and independent judicial bodies,

2. State judicial control prevents illegal actions and plays a key role in ensuring the rule of law,

3. State judicial control is regulated by administrative law, 
4. Judicial bodies and relevant state bodies where control is exercised shall be obligatory participants in the activity of state judicial control. Two aspects of the implementation of state judicial control come to the fore;

- The protection of the rights and freedoms, legitimate interests of citizens, prevention of illegal activities in the activities of state bodies.

- State judicial control has a number of tasks aimed at preventing negative developments in public administration, increasing the efficiency of government agencies and ensuring the rule of law. These responsibilities are;

Control over the protection of the rights and freedoms of citizens

Control over the legal activities of state bodies

To exert legal influence on state bodies

Strengthening discipline in public administration

Increasing the sense of responsibility

Elimination of contradictions between legal norms

Protection of national interests

Fight against corruption

Formation of ethical norms of behavior.

In modern times, the rapid development of state-citizen, state-society relations increases the importance of judicial control. For this reason, there is a need to create a single, transparent judicial control system. Judicial control ensures the protection of the rights and freedoms of citizens.

State judicial control is important in the legal education of society, in the explanation of the rules of appeal to the judiciary, in the legal development of statecitizen relations (Тихомиров, 2008:446). In modern times, state judicial control seeks to address the following pressing issues (Abdullayev, 2012:332);

- To provide citizens with convenient and easy access to the judiciary

- To increase the confidence of citizens in the judiciary

- Possibility of a real defense mechanism against illegal decisions taken by state bodies, violation of rights and freedoms 
- To propagandize in society about the importance and significance of judicial control.

Judicial control ensures the participation of citizens in public administration activities, creates conditions for them to apply to the judicial authorities about violations of the law. Judicial control observes over the lawful functioning of state bodies. At the same time, judicial control provides citizens with opportunities to analyze and evaluate the adopted state laws. From this point of view, judicial control ensures the protection of not only society and citizens, but also the interests of the state. One of the main functions of the state through judicial control is norm control. Norm control means processes such as Analysis of existing legislation, the change or elimination of detected violations, and so on.

State judicial control is carried out on the basis of the principles of legality, independence, justice, objectivity and honesty. The development and improvement of state judicial control, which is one of the main conditions of the rule of law in modern times, is one of the most common issues of the legal policy of any state.

In general, state judicial control begins with the legal expression of public condemnation, is accompanied by the power of the state, and acts as a guarantee of legality, objectivity and efficiency in the activities of state bodies. At the same time, state judicial control plays an important role in the formation of a fair and transparent judicial system, the protection of human rights and freedoms, and the legal functioning of state bodies (Bayramzade, 2017:132).

\subsection{Constitutional Control of the State}

One of the main forms of the state control system in modern times is constitutional control. Constitutional control is a set of measures such as the functioning of state bodies in accordance with the requirements of the constitution and the elimination of unconstitutional circumstances. State constitutional control is the main form of ensuring constitutional supremacy. In scientific sources, constitutional control is used in the sense of «constitutional law», «constitutional justice». Constitutional control includes issues such as checking the compliance and implementation of adopted laws with constitutional requirements, repeal of acts that do not comply with constitutional 
requirements. There are three forms of state constitutional control (Habibova and Abdullayeva, 2018:232);

- Abstract constitutional control

- Specific constitutional control

- Individual or collective constitutional control

Abstract constitutional control implies the observance of constitutional provisions expressing the protection of human rights and freedoms in the adoption of laws, normative legal acts. This form of constitutional control is typical for European countries (France, Italy, Germany, Spain, etc.) A specific form of constitutional control expresses a concrete solution to the constitutionality of the applied norms and legislative acts. During this form of control, the general judiciary has the power to determine the constitutionality of legislative acts by sending a request to the Constitutional Court. An individual or collective form of constitutional review is carried out on the basis of individual or collective complaints. Civil societies or individuals may send a complaint to the Constitutional Court regarding violations of their rights and laws. This form of constitutional control is provided in three cases (Jafarli, 2018:234);

- Complaints sent should be of constitutional significance

- Complaints sent must be well-founded

- Complaints sent should be promising.

Constitutional control, which is the basis of the legal control system of the state in modern times, has a number of functions. These functions are (Huseynova, 2013:258);

- Political function

- Regulatory function

- Protection function

- Ideological function. 
Political function means making decisions and laws in order to create a stable political environment. Constitutional control eliminates disagreements and conflicts between state bodies and ensures political stability (Askerov, 2011:760).

The regulatory function provides for the regulation of the lawful activities of state bodies. This function of constitutional control is carried out in two directions (Huseynova, 2013:322);

- Elimination of violations of the requirements of the Constitution

- Creation of new legal norms in accordance with the Constitution.

The protective function provides for the adoption of appropriate legal measures against public authorities and responsible people who go beyond the requirements of the constitution. The ideological function means the ability of the constitution to influence the characteristics (moral, psychological, moral, legal, and religious, etc.) formed during the history of each country. In the world practice, three approaches to the theory of state constitutional control are pin dependence.

1. Natural legal theory

2. Organic theory

3. Institutional theory

In some literatures, natural legal theory is used in the form of social contract theory. In organic theory, the constitution is the highest law of any state, and therefore other laws must have a lower legal effect than the constitution. Thus, no legal force can be unconstitutional. According to institutional theory, the constitution defines the powers of state bodies and prevents outside interference in the established powers.

State constitutional control has a number of important functions. These responsibilities include verifying the constitutionality of adopted laws and acts, eliminating existing irregularities in the field of legislation, and resolving disputes within the legal framework. Constitutional control is the most important condition of the rule of law. Execution of state constitutional control is carried out by a number of control bodies. The oversight bodies are closely linked to each other. This, in turn, 
creates the basis for the transparent and effective implementation of constitutional review. Bodies exercising state constitutional control are divided into 2 groups: specialized oversight bodies and other control bodies.

Specialized constitutional oversight bodies include constitutional courts and committees established within constitutional courts. Other constitutional oversight bodies include parliament, government, judicial oversight, and the prosecutor's office. Constitutional control is central of the legal policy of the world. In world practice, there are American and European models of constitutional control. In the American model, constitutional review is exercised by the judiciary. This model is mainly used in the United States, Scandinavia, Latin America, Japan, Norway and Malta. In the American model, because constitutional review is exercised by the courts of general jurisdiction, if the judiciary deems any legislative act unconstitutional, that act loses its legal significance and is annulled. In the European model, constitutional oversight is exercised by committees and courts set up by specialized experts. The European model has been created in Austria for the first time in the world. This model is mainly characteristic of European countries and CIS countries.

In the general sense, constitutional control is a mechanism that monitors the constitutionality of acts, decisions and laws adopted, designed to ensure the supremacy of the Constitution, protection of the rights and freedoms, interests of citizens, the effective and efficient functioning of the legal system of the state (Bozoghlu, 2008:18).

\subsection{Social Control}

One of the main forms of the state control system is social control. Social control is a mechanism of processes that determine the norms of human behavior in society and create discipline. Social control, which covers various processes related to human behavior, plays an important role in the development of society. In sociology, the concept of social control is defined in two ways. The first direction envisages measures taken to regulate the behavior of individuals in society. In the second direction, people are expected to follow certain norms of behavior in society. Social control is one of the most effective ways to regulate the processes taking place in society. In this sense, the formation and application of a system of social control in society is inevitable. In a 
society without social control, chaos reigns. Social control has two functions. These functions are (Rzayev, 2011:480);

- Protective function

- Stabilizing function

Protective function protects society from social problems, chaos. The stabilizing function serves to ensure social stability in society. Both functions of social control are closely related and complement each other. In general, the functions of social control can be defined as follows: The function of protection ensures and protects the rights and freedoms of people in society. Ensuring and protecting these rights creates a stable social environment. The scientific literature states that the mechanism of social control consists of three structural elements. These elements are (Alirzayev, 2010:326);

- Power

- Norms

- Sanctions.

The government is the main instrument of social control. Through this element, laws and codes of conduct are formed and their implementation is monitored. The concepts of social control and power are closely linked. Thus, any individual can carry a certain small function of power. Power is divided into three main aspects (Vahidov, 2009:334);

- The Directive Aspect: The directive aspect, which is the leading aspect of power, envisages the implementation of decisions and laws.

- Functional Aspect: The functional aspect refers to the exercise of the government's public administration function.

- Communicative Aspect: The communicative aspect refers to the exercise of power through communication that is understandable to society. 
The second structural element of the social control system includes norms. Norms are the requirements that determine the rules of good behavior in society. Norms of special importance in the management of society and the implementation of social control determine what is forbidden and what should be done. Norms are important for the following purposes (Hasanov, 2010:208);

- Forms and ensures stability in society

- Prevents social chaos

- Unites society closely

- Social norms are the first weapon of power, and control of these norms is the second weapon of power.

The third structural element of the social control system includes sanctions. Sanctions are activities that stimulate society to adhere to accepted social norms. Social sanctions are divided into two aspects in terms of compliance with the norms: the negative aspect and the positive aspect. The negative aspect is the implementation of punitive measures in case of violation of the norms. On the positive side, it provides for the implementation of rewarding measures in case of compliance with the norms. Sanctions play an important role in the implementation of social control. The importance and role of social control, which plays an important role in ensuring internal order and stability in society, is constantly growing. In this sense, the formation and development of the system of social control in modern times is the focus of the world's states (Huseynova, 2011:456).

\subsection{Public Control}

One of the control systems applied in public administration in modern times is the public control system. The main purpose of the application of public control is to support the harmonization of decisions with the legislation, improving the quality of work of government agencies and the protection of the rights and freedoms of citizens. The application of public control over public administration activities increases flexibility and efficiency in governance. Public control is exercised through a number of 
bodies and associations. The organization of public control is carried out through the following institutions (Alakbarov, 2018:216);

- Public observation commissions

- Public inspections

- Public control groups

- Civic associations

- Other bodies

Public control plays an important role in obtaining accurate information on the activities of government agencies. In world practice, the application of public control is carried out in the following forms (Guliyev, 2013:828);

- Public monitoring

- Public inspection

- Public expertise

- Public discussion

- Public observation

- Public listening

Public control that creates a balanced relationship between the state and society is based on the principles of accountability and equality. In addition to the forms of control mentioned above, there are a number of additional forms of state control. Other forms of state control include environmental control, immigration control, price control, quality control, certification control, import-export control, etc. Includes. In general, it is necessary to introduce a system of state control that plays a regulatory and stabilizing role in public administration. The application of the state control system is one of the main conditions for effective and efficient management. Recently, the development of market relations, the increasing complexity of society further increases the importance and role of the control system in public administration (Memmedov, 2013:17). 


\subsection{State Control System in Azerbaijan}

The state control system in the Republic of Azerbaijan includes the processes as the implementation of state policy, control over the implementation of decisions and activities of state bodies, ensuring the rule of law in the field of public administration. The control system of public administration in Azerbaijan can be analyzed from three aspects;

- Social aspect

- Legal aspect

- Management aspect

The social aspect is characterized by the dominance of social relations and this plays an important role in the formation, functioning, and development of the social system. The social aspect of control helps to eliminate negative situations in society and governance. The social aspect plays an important role in solving three issues in the field of public administration;

- Achieving social goals

- Management of society

- Formation of norms of behavior

In the general sense, the social aspect of control is an important function and subjective rights of public entities. The legal aspect ensures the legality of management activities and compels control subjects to act within the law. The management aspect acts as an evaluation mechanism in the management of the state and society. It is impossible to carry out management activities without a control system. In this regard, control is (Qandilova, 2010: 320);

- A specific and integral part of management activities

- A source of information necessary for decision-making in the management process 
- Checking the actual state of control objects in the management process.

An important condition for state control is that the activities carried out in the field of public administration in Azerbaijan meet the requirements of existing legislation, ensure transparency and accuracy.

State control measures in Azerbaijan include such processes as inspections, analyzes, examinations and opinions on the current situation.

\subsection{Stages of Implementation of State Control in Azerbaijan}

State activity in Azerbaijan is carried out in four stages;

- Preparation for control

- Planning of control

- Collection, categorization, and analysis of data

- Execution of control

The control preparation phase is carried out before starting of the control activity and communication with the control object is established. The following documents are required at the stage of preparation for control (Habibova and Abdullayeva, 2018:232);

- Questionnaire of the object of control

- Questionnaire of the body exercising control

- Order on control

- Explanatory request on the control

- Request for confirmation

- Registration document of answers.

The planning stage of the control depends on the direction, scope, assessment of existing risks, etc. of the control activities to be carried out at this stage. Issues such as according to the results of the analysis, planning work is carried out. The following documents are required at the control planning stage; 
- General control plan

- Financial (profit and loss) statement of the controlled entity

- Balance sheet of the enterprise

- Risk measurement and grading

- Schedule for assessing the general condition of the controlled entity

Data collection, categorization, and analysis are carried out and the information that is relevant is collected, grouped, and analyzed on the basis of this information. The following processes are carried out at the stage of data collection, grouping, and analysis;

- Receipt of all documents related to the object of control

- Verification of information accuracy and reflection in reports

- Conducting analyzes (tax accounting, accounting and employee reporting)

- Accounting for intangible assets and checking the alignment of official registration

- Legislative and legal review of contracts

- Execution of control

At this stage, the current status of the object of control is determined, the necessary measures are taken against the detected illegal and negative cases. The following documents are required at the stage of control implementation (Rzayev, 2008:307);

- List of revealed illegal and negative cases

- Final results of control activity

- List of objections

- Control report.

\subsection{State Financial Control}

In Azerbaijan One of the main forms of state control in Azerbaijan is the state's financial control. State financial control is carried out by the following state bodies (Haciyev, 2018:416); 
- Chamber of Accounts of the Republic of Azerbaijan

- Department of State Control of the Executive Office of the President; - Ministry of Finance of the Republic of Azerbaijan

- Ministry of Taxes of the Republic of Azerbaijan

- The State Customs Committee

- Central Bank of the Republic of Azerbaijan

- Chamber of Auditors.

\subsection{Forms of State Financial Control in Azerbaijan}

The following main forms of state financial control are available in Azerbaijan (Bagirov and Hasanli, 2011:384);

- Customs Control

- Budget Control

- Tax Control

- Currency Control

- Bank Control.

Customs control, entry of goods and means of transport into the customs territory, removal from the customs territory, transportation, etc. control processes carried out in order to control the processes and ensure compliance with the customs legislation. The subject of state customs control includes goods and means of transport, all their types. From the legal point of view, state customs control consists of a set of inspection control measures carried out by the customs authorities of the Republic of Azerbaijan in order to ensure the fulfillment of the Constitution of the Republic of Azerbaijan, relevant legislation, and international agreements (Khankishiyev, 2012:41).

Budget control consists of a set of control measures related to budget activities, determined on the basis of legal norms and implemented by the relevant control bodies. Budget control measures include control, justification, and evaluation of budget revenues and expenditures, timely and complete implementation of budget processes. 
State budget control plays an important role in the implementation of the following tasks (Muslimov and Kazimov, 2011:312);

- Ensuring compliance with the legislation of the Republic of Azerbaijan and other relevant financial acts related to budget activities,

- Ensuring the formation and targeted use of budget revenues,

- Negative situations and legislation in the field of budget activities prevention of violations,

- Control over inter-budgetary processes, etc.

Decisions and steps taken in the field of budget control in Azerbaijan are yielding positive results, as a result of an increase in state budget revenues of the Republic of Azerbaijan over the years is observed (Figure 1).

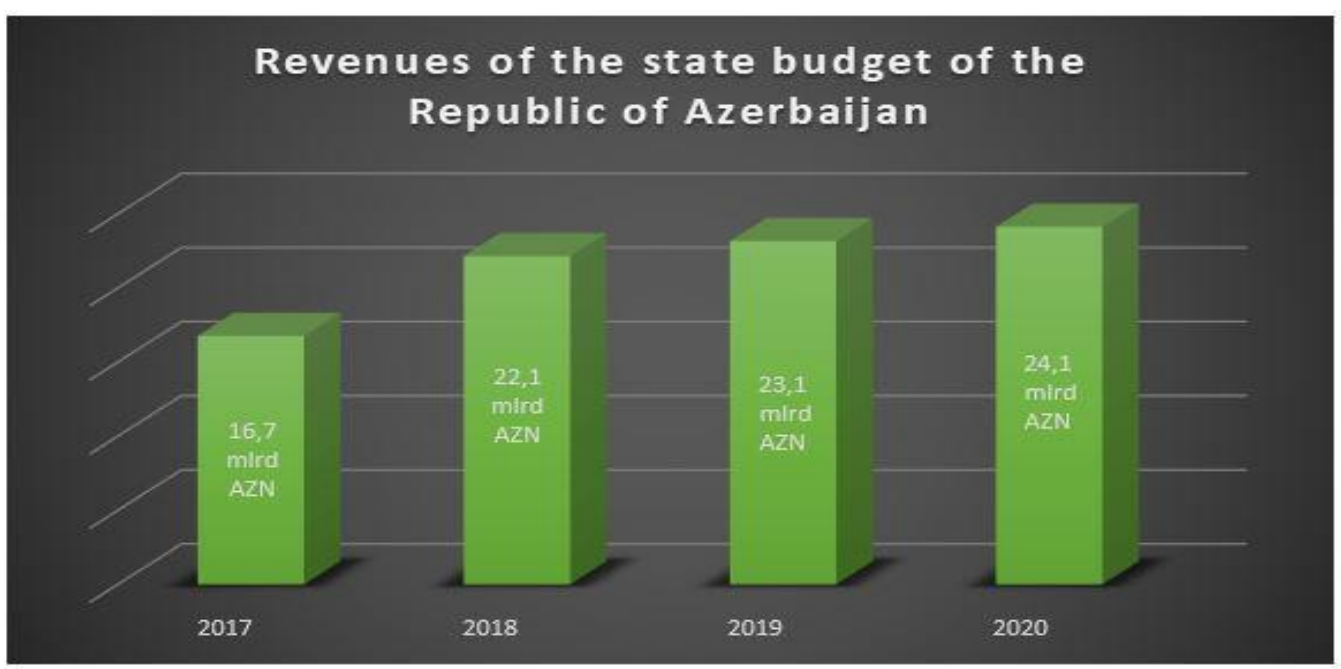

Figure 1. Revenues of the state budget of the Republic of Azerbaijan

The budget control mechanism carried out in Azerbaijan plays an important role in the development of the country's economy, the development of a sound budget policy, and the efficient and effective use of budget funds.

Tax control covers such processes as compliance with tax legislation and relevant legislation, timely and complete payment of tax payments, prevention of tax evasion, accurate calculation of taxes, and the creation of a transparent tax environment. The 
state tax control system plays an important role in ensuring the economic security of the state. State tax control in Azerbaijan is one of the key elements ensuring the normal functioning of tax policy.

To this end, tax reforms are aimed at improving the tax system and bringing the tax control mechanism in line with modern world standards. State tax control in Azerbaijan is based on the principles of government. Sanctions and fines are imposed if necessary during a tax control. The applied sanctions and forms of fines are determined by the legislation (Musayev and Qahramanov, 2010:343). As a result of the steps taken and measures taken in the field of tax control in Azerbaijan,a significant increase is observed in the number of taxpayers.

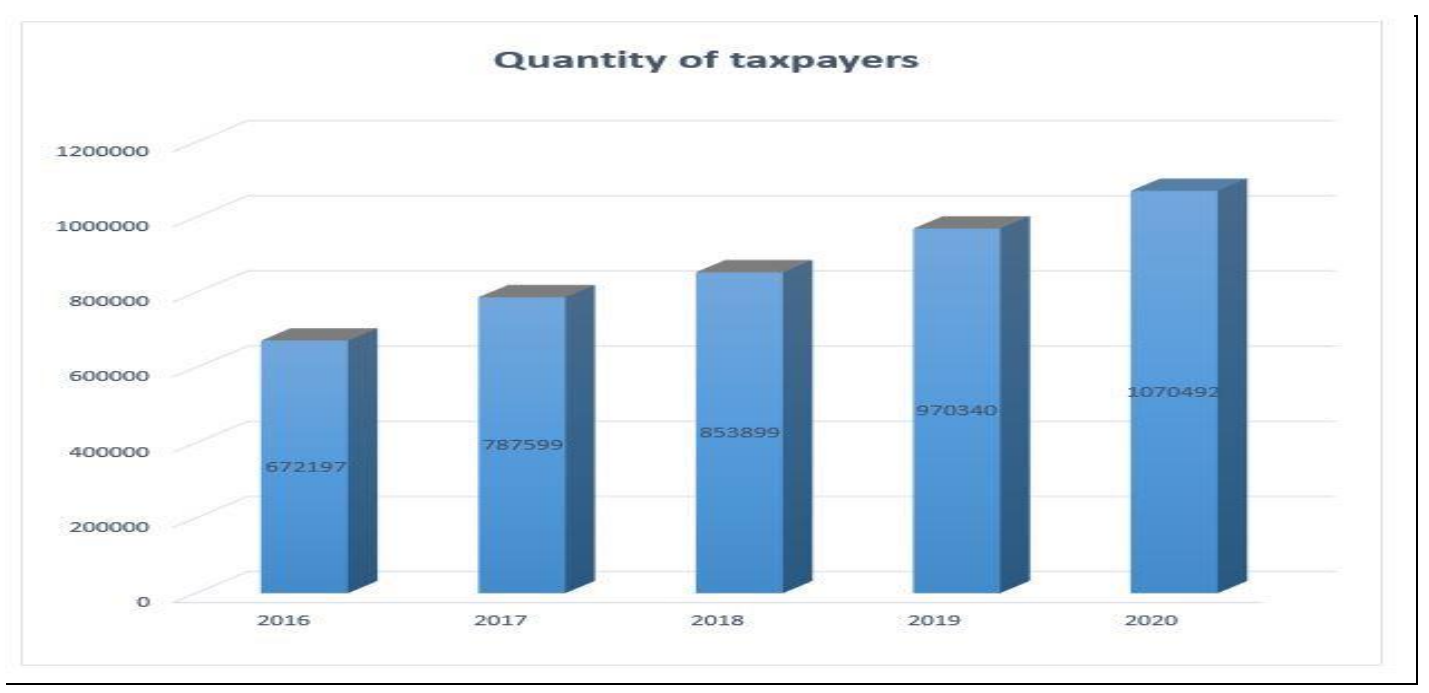

Figure 2. Quantity of Taxpayers

Resource: www.taxes.gov.az/ 
At the same time, there was an increase in the amount of tax revenues.

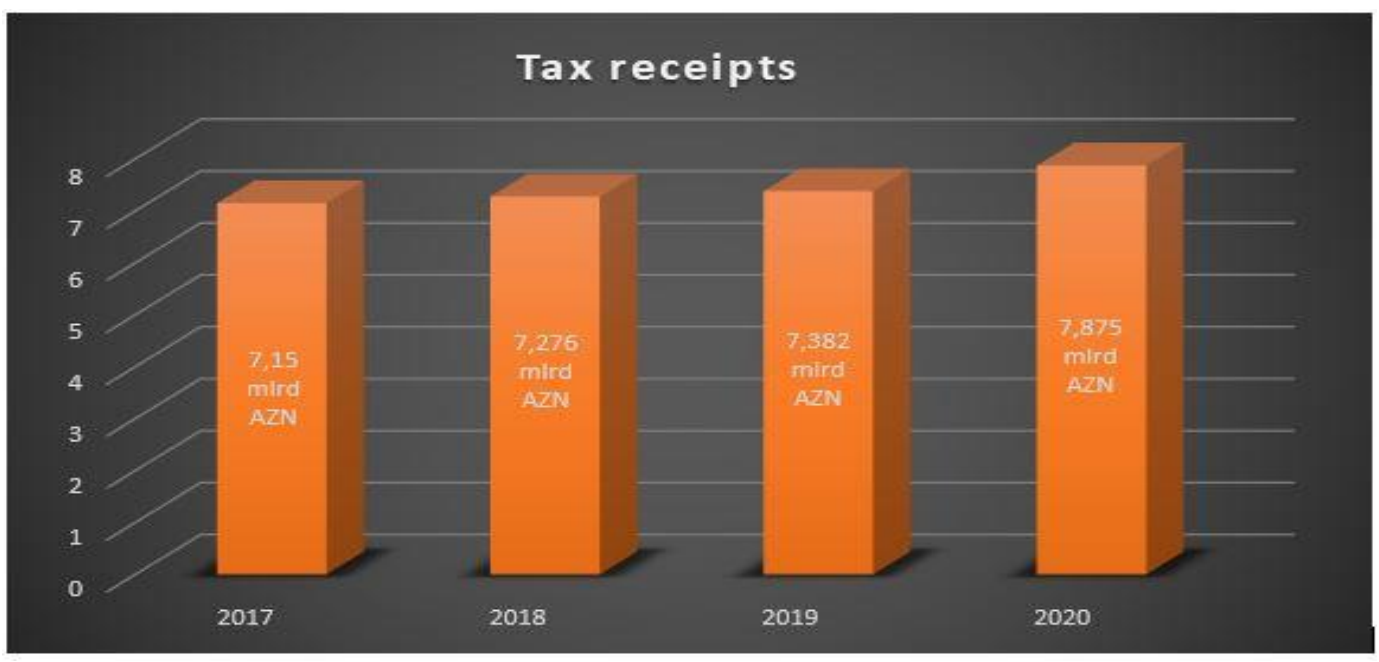

\section{Figure 3.Tax Receipts}

Resource: www.taxes.gov.az/

As it can be seen from the statistics, the measures taken in the field of tax control gave its benefit, and as a result, the number of taxpayers, tax revenues grow at an increasing rate over the years. In modern times, the importance of tax control in relation to the development of a market economy in Azerbaijan has become even more important. State tax control plays an important role in the socio-economic development of entrepreneurship and regions, ensuring transparency in the field of taxation and improving financial discipline. In order to improve the mechanism of state tax control in Azerbaijan, along with the adoption of laws and decisions, changes and additions are made to the relevant legislation (Macidov, 2013:506).

Currency control covers processes such as state management of the foreign exchange market on the basis of legislation, stabilization and regulation of the national currency, etc. Recent dynamic globalization has made it necessary to further improve state currency control in Azerbaijan. A number of measures have been taken in this direction. These measures are as follows (Hajiyev and Shahrza, 2012:346);

- Comprehensive (quantitative and qualitative) coordination and harmonization of economic development in Azerbaijan and the obtained macroeconomic results with the dynamic process of globalization in the world. 
- Ensuring national economic stability and development of Azerbaijan and maximum use of development prospects.

- To expand the sphere of influence of currency control and currency regulation, to carry out regular improvements in these areas.

- Harmonization of national currency legislation and other normative acts with international norms and standards, taking into account national interests in Azerbaijan.

Effective organization of the principles, implementation procedures, accountability, and other features of the state currency control policy will ensure effective regulation of both the domestic monetary system and foreign exchange inflows.

Banking control refers to the control over the activities of commercial banks and other credit organizations operating in the country. The implementation of state banking supervision plays an important role in terms of managing possible risks in the banking sector, ensuring the fulfillment of the bank's obligations, maintaining the financial stability of banks and other credit institutions. At the same time, the main objectives of state banking supervision include ensuring financial stability, protecting bank customers from losses, and preventing economic crimes. The role of financial control is growing significantly in modern Azerbaijan, where radical socio-economic reforms are being implemented, state policy is dominating in strengthening the rule of law in the financial sector, and a democratic, legal society is being established. At the same time, the mechanism of public financial control plays a key role in the economic development of the country and the formation of a stable economic environment, and it is one of the main factors for making the formation of an effective financial control system in Azerbaijan. Additionally, forming the state financial control mechanism that responses to the requirements and the modern standards and increment of its efficiency are one of the important goals of the state's economic policy in Azerbaijan (Hajiyev, 2010:101).

\subsection{Other Forms of State Control in Azerbaijan}

The control mechanism in Azerbaijan covers all areas of public administration. In this regard, a number of forms of control over public administration are applied in 
Azerbaijan. Let's take a closer look at the forms of state control systems implemented in Azerbaijan and their features.

\subsubsection{Constitutional Control}

One of the main forms of state control in Azerbaijan is constitutional control. Constitutional control is a system of legal control that includes such processes as ensuring the supremacy of constitutional requirements, rights, and freedoms of citizens, identification and repeal of legislative acts contrary to constitutional requirements, control over the constitutionality of adopted laws. Constitutional control in Azerbaijan is exercised through the Constitutional Court of the Republic of Azerbaijan. The Constitutional Court has broad oversight powers. Using these powers, the constitutional court controls the overall legislative mechanism of the Republic of Azerbaijan. In Azerbaijan, constitutional control is exercised in two forms according to the period of implementation (Abdullayev, 2013:663);

- Initial constitutional control

- Subsequent constitutional control

Initial constitutional control means the examination of laws and normative legal acts before their adoption. Subsequent constitutional review is intended to be carried out in order to verify the legal effectiveness of laws, normative legal acts, orders after their entry into force. In modern times, constitutional control plays an important role in protecting the rights and freedoms of citizens, the formation of a stable social environment. At the same time, transparent constitutional oversight is an indicator of democracy and a guarantee of legal stability.

\subsubsection{Judicial Control}

One of the main forms of state legal control in Azerbaijan is judicial control. Judicial control in Azerbaijan means control measures carried out by the judiciary against criminal, search, investigation, investigation, and other law enforcement agencies. The main activities of the judiciary include ensuring the personal interests, freedoms, and other rights of citizens, the application of coercive procedural measures, ensuring 
transparency in the administration of justice. Judicial control over the administrative bodies of the state creates conditions for the elimination of decisions, legislative acts, and administrative acts that are not in the interests of society. Judicial control in Azerbaijan is analyzed in three directions (Abdullayev, 2010:344);

- $\quad$ Control over the legal settlement of legal disputes by administrative courts

- Control over the provision of rights and freedoms of citizens

- Control over general management, rule-making, and law enforcement activities.

\subsubsection{Public Control}

One of the main forms of state control in Azerbaijan is public control. Public control is exercised through public councils, non-governmental organizations, the media, trade unions, neighborhood committees of municipalities, and initiative civic groups.

One of the main issues that the state pays attention to in Azerbaijan is the existence of public control over the central and local executive authorities and local selfgovernment bodies. For this purpose, public control councils have been established in Azerbaijan within a number of ministries. In addition, public oversight councils have been established in a number of Azerbaijani state universities along with government agencies (Vahidov, 2009:334). The main purpose of public control councils established within state ministries and universities is to implement public control over the activities of ministries, ensure effective operation and transparency, and develop effective proposals for establishing direct and effective relations between society and state ministries.

\subsubsection{Presidential Control}

The main form of state control in Azerbaijan is presidential control. Presidential control is a mechanism to ensure human rights and freedoms, control the "confidential" economy, corruption and bribery, and crime. The main directions of the President's control are control over the observance of laws, strengthening executive discipline, strengthening the mechanism of public administration, radically improving the activities of law enforcement agencies aimed at ensuring the security of the individual, society 
and the state, ensuring the unity of state legislature, executive and judiciary. processes include. In Azerbaijan, presidential control is exercised by the presidential institution through branches of government. The main purpose of presidential control is to bring the activities of the state executive bodies in line with the requirements of the president, public administration and legislation.

The functions of presidential control in Azerbaijan are performed by the Presidential Administration of the Republic of Azerbaijan. Subjects of presidential control are classified into three forms according to the degree of supremacy (Rzayev, 2011:480);

- $\quad$ Higher-level - President

- Secondary level - Presidential Administration

- Third level - Presidential representations on the sectors (executive authorities).

Presidential control, which is an important and strategic part of the state control mechanism, not only controls the activities and management of the state executive bodies, but also serves to strengthen and legitimize the executive bodies and eliminate violations of the law in according to the constitutional requirements.

\section{Conclusions and suggestions}

In modern times, the role and importance of the control system in public administration is increasing. The control system in public administration is a system consisting of checking the implementation of constitutional requirements, legislation, norms and standards, identifying existing problems and taking appropriate steps to eliminate these problems. The control system ensures the stability of management activities through the use of regulatory measures.

The function of control, which is one of the main functions carried out by the state, regulates the state-society relations, ensures the development of social, economic, social and legal spheres of the state. The system of state control plays a special role in the development of the state. Experiments have shown that without a control system it is 
impossible to achieve development. Based on the research carried out in the research paper, the following conclusions and suggestions were put forward;

- The state control system is a set of processes conducted for the purpose of detection and elimination of illegal situations in the management activity, ensuring the lawful activity of management, efficient, purposeful and appropriate use of resources.

- The system of state control ensures transparency and efficiency in management, plays a key role in the formation of a stable society, the development of state-society relations and social, economic, legal, areas of the state.

- The existence of a transparent control mechanism is one of the basic principles of a democratic state.

- The principles of control and legislative requirements must be observed to ensure the effectiveness of control in public administration.

- $\quad$ Personnel and base resources for state control activities should be increased, and trainings and seminars should be organized in order to improve the knowledge and skills of the existing personnel resources.

- Problems in the state control system should be determined, circumstances hindering the implementation of governance reforms should be identified, and appropriate recommendations should be developed to prevent such cases.

- The activities of control bodies performing the same function, should be clarified, merged or abolished if necessary.

- $\quad$ The role of public entities in state control activities should be expanded.

The system of control in public administration is directly proportional to the development of the state. For this reason, special attention is paid to the formation of an effective state control mechanism, the proper implementation of control activities, compliance with the principles of organization of control and other such issues.

The analysis shows that there have been serious changes and developments in the field of state control in Azerbaijan recently. So, in recent years, Azerbaijan has strengthened control over the activities of government agencies, transparency of information in government agencies, legal responsibility, and accountability. At the same time, it was determined that the state control system has played a special role in 
the implementation of radical reforms in Azerbaijan in recent years. At present, the formation of a system of control over management activities that meets world standards, ensuring transparency in the field of state control, progressive regulation, and ensuring professionalism in the implementation of control systems are ones of the main priorities of state policy.

At the same time, there are some problems in the state control system in Azerbaijan and a number of improvements are needed. Thus, it is necessary to improve the bodies performing control activities in the Republic of Azerbaijan. In this time, it would be appropriate to study the experience of a number of developed countries and apply it to Azerbaijan.

However, the relevance of the practice to be applied in this case must be taken into account in accordance with the national mentality, traditions, social psychology, culture, and values inherent in Azerbaijan. There are the following problems in the organization of the public administration control system in Azerbaijan;

- $\quad$ Scarcity of a single legislative act related to state control activities.

- $\quad$ Adequacy of adequate measures taken for violations detected during control activities.

- Unsatisfactory level of training for control bodies.

- Lack of internal control departments in plenty of local and central executive bodies.

- $\quad$ Formal functioning of control bodies operating within a number of local and central executive bodies. In order to eliminate these problems, it is necessary to adopt a law related to the State Control System. The law should reflect the forms of organization of state control, principles of control, purposes of control, uniform norms, and standards of control.

It would be sufficient to implement the following system of measures for the development of the state control system in Azerbaijan; 
- Preparation of reports on the activities of state control bodies.

- $\quad$ Establishment of electronic control ("e-control") system.

- Establishment of internal control councils in state bodies or improvement of the activity of existing control councils.

- Study and application of international experience.

- Training of qualified personnel in the sector of control and improvement of existing personnel potential.

- $\quad$ Continuously educating citizens about the nature, purpose, and importance of the control system.

\section{Disclosure statement}

No potential conflict of interest was reported by the author.

Contact Information

E-mail: xetai.salmanov@list.ru 


\section{References and notes:}

Abbasov, Ibad and SADIGOV, Rahim (2013), Management: Textbook, Bakû Business University Publication, Bakû.

Abdullayev, Abdulali and Gadimalıyev, Araz (2012), Administrative Process: Textbook, Law Publishing House, Bakû.

Abdullayev, Farhad (2010), Theoretical And Practical Problems of Constitutional Proceedings in The Republic of Azerbaijan, Zardabi Publishing House, Bakû.

Abdullayev, Farhad (2013), Legal Positions of The Constitutional Court of The Republic of Azerbaijan, Zardabi Publishing House, Bakû.

Alakbarov, Urkhan (2013), Fundamentals of Sustainable Human Development And Ecological Civilization: Textbook for Higher Education, Education Publishing House, Bakû.

Alakbarov, Urkhan (2018), Fundamentals of Inclusive Development Management: Textbook for Higher Education, Education Publishing House, Bakû.

Alırzayev, Ali (2010), Economics And Management of The Social Sphere, University of Economics Publishing House, Bakû.

Alıyev, Teyyuh, Alıyeva, Shams and Alıyev, Ramil (2012), Management of Human Resources: Textbook, ADNA Publishing House, Bakû.

Alıyeva, Yasemen (2012), Fundamentals of Management: Textbook, Cooperation Publishing House, Bakû.

Askerov, Ziyafet (2011), Constitutional Law, Bakû University Publishing House, Bakû.

Bagırov, Damat and Hasanl, Miralam (2011), Finance: Textbook (Second Edition), University of Economics Publishing House, Bakû.

Bayramzade, Khanlar (2007), Control of Operational And Search Activities, Bakû University Publishing House, Bakû.

Bozoğlu, Menekşe (2008), “Kamu Yönetiminin İdari Denetimi ve Ombudsmanlık Kurumu”, Yüksek Lisans Tezi, Selçuk Üniversitesi Sosyal Bilimler Enstitüsü, Konya.

Gandılov, Sadaqat (2010), Theory of Public Administration: Textbook, Science and Education Publishing House, Bakû.

Gandilova, Seadet (2010), Public Administration Theory: Textbook, Science and Education Publishing House, Bakû.

Guliyev, Tofiq (2013), Human Resource Management, Nagil Evi Publishing House, Bakû.

Habibova, Ziyafat and Abdullayeva, Maftuna (2018), Change Management and Public Administration, Education Publishing House, Bakû.

Hacıyev, Fazil (2018), Economic Analysis in The Audit: Textbook, MSV Publishing House, Bakû.

Hajıyev, Fazil and ALIYEV, Shahrza (2012), Audit: Textbook, Indigo Publishing House, Bakû.

Haj1yev, Rauf (2010), Fundamentals of Auditing, Indigo Publishing House, Bakû.

Haj1yev, Shamseddin (2011), State and Municipal Administration, Indigo Publishing House, Bakû.

Huseynov, Reshad (2017), Legal State And Civil Society, Science And Education Publishing House, Bakû.

Huseynova, Nazenin (2013), Civil Service and Personnel Policy, Adiloglu Publishing House, Bakû.

Jafarli, Hanifa (2018), Management Analysis: Textbook, University of Economics Publishing House, Bakû.

Khankıshıyev, Beybala (2012), Financial Control, University of Economics Publishing House, Bakû.

Macıdov, Mobil (2013), Tax System: Textbook, Bakû Business University Publishing House, Bakû.

Mahmudov, Matlab, Shabanov, Zinaddin and Alakbarov, Faiq (2012), Management Theory: Textbook, Science and Education Publishing House, Bakû.

Memmedov, Fuad (2013), Management Culture, Experience of Foreign Countries, Science and Education Publishing House, Bakû.

Musayev, Akif and QAHRAMANOV, Aslan (2010), Tax Culture, Caş1oğlu Publishing House, Bakû.

Muslimov, Salim, KAZIMOV, Rashib (2011), Financial Analysis: Textbook, Azerneshr Publishing House, Bakû.

Rzayev, Ali (2008), State Control: Theory And Practice, Science Publishing House, Bakû.

Rzayev, Ali (2011), Legal Bases of Civil Service: Textbook, Science Publishing, Bakû.

Rzayev, Qahraman (2011), Control and Inspection: Textbook, Adiloglu Publishing House, Bakû.

Тихомиров, Юрий (2008), Современное Публичное Право, Москва.

Vahıdov, Fazil and AGAYEV, Tahir (2009), Sociology, Taknur Publishing House, Bakû.

www.customs.gov.az (Date of Access: 08.01.2021).

www.taxes.gov.az (Date of Access: 08.01.2021).

Int.J. Hum. Soc. Dev. Res.

Volume 5, № 2, 2021.72-105 